\title{
An Improved Assessment of Personality Traits in Software Engineering
}

\author{
A. S. Sodiya \\ University of Agriculture, \\ Abeokuta, Nigeria \\ sinaronke@yahoo.co.uk \\ S. A. Onashoga \\ University of Agriculture, \\ Abeokuta, Nigeria \\ bookyln@yahoo.com
}

\author{
H. O. D. Longe \\ University of Lagos, \\ Lagos, Nigeria \\ hodlonge@yahoo.co.uk \\ O. Awodele \\ Babcock University, Ilishan, \\ Ogun, Nigeria \\ delealways@yahoo.com
}

\author{
L. O. Omotosho \\ Bowen University, Iwo, Nigeria \\ inedune@yahoo.com
}

\begin{abstract}
The success or otherwise of Software Engineering (SE) activities depends on the interactions among software engineers. Consequently, effective interactions depend largely on personality traits, which is a consistent and long-lasting tendency in behaviour. In psychology, five major trait factors (The Big Five Factors) have been generally used to assess personality of people. But, these might not be adequate in SE because of the required technical and cognitive skills. In this work, we first present Cognitive Ability as an additional factor that must be measured in order to adequately assess personality in SE. A research survey was conducted in order to capture personality requirements in SE. Based on the result of the survey conducted, we develop a model for assessing personality traits in SE. We then design an assessment technique that is based on responses to some well-structured and deductive on-line questions. The implementation of the model using Visual Basic resulted in a much-needed tool that can guide intending software engineers in choosing area of specialization in SE based on their personality traits.
\end{abstract}

Keywords: Software Engineering, Software Engineers, Personality Trait, Psychology

Material published as part of this publication, either on-line or in print, is copyrighted by the Informing Science Institute. Permission to make digital or paper copy of part or all of these works for personal or classroom use is granted without fee provided that the copies are not made or distributed for profit or commercial advantage AND that copies 1) bear this notice in full and 2) give the full citation on the first page. It is permissible to abstract these works so long as credit is given. To copy in all other cases or to republish or to post on a server or to redistribute to lists requires specific permission and payment of a fee. Contact Publisher@InformingScience.org to request redistribution permission.

\section{Introduction}

Software projects often involve composition of teams to handle different tasks within the software project. Each team is then charged with role or task that represents part of the total job to be carried out. The major objective of any software project is to make the project successful. A successful software project is the one 
that is delivered on time, within budget and with the required quality (Hughes \& Cotterell, 2002). This implies that for the overall project to be successful, each team's goal or subproject must also be successful. The success or otherwise of a team depends largely on the interactions among the members. Effective interactions among members are influenced by the personality traits possess by members. A personality trait is defined as a consistent, long-lasting tendency in behavior (Kalat, 1999).

Consequently, one may conclude or infer that the major development tool in any software project is people. Getting the people, not only with the right technical skills, but also with the right personalities is paramount to the success of any software project. Howard (2001) stated that knowing the qualifications, technical skills, and experience of team members is well and good, but equally important is to understand the different working personalities of software developers. The secret of productivity is to match the requirements of a particular project with the personalities of members.

Effective team formation in software development is difficult to achieve and requires careful amalgamation of personality traits. It is then important to have an efficient way for assessing the personalities of software engineers so as to predict their conformity to the task and responsibilities of software development. Young et al., (2005) mentioned that an informal discussion (independently held) with another member of staff in an organisation had revealed a case of good "programmer" with sound analytical skills who had left the company because he could not work within a team focus.

This study presents a technique for personality traits assessment in software engineering. A tool is then developed using Visual Basic to capture personality characteristics of software engineers. The tool requires responding to an expert on-line questionnaire and determines personality status of software engineers in relation to their nature of jobs. The questions are indirect and structured in a way that respondents do not actually know their relationships with a particular trait.

The structure of this paper is as follows. The next section discusses previous related works. A review of personality trait and software development and the architectural design are presented in the third section. The implementation of the personality assessment technique is presented in the fourth section. We present future work and conclusion in the fifth section.

\section{Related Works}

The study of personality started over 100 years by researchers in psychology. A recent work on personality is on meta-analytic review of Big Five personality factors and accident involvement in occupational and non-occupational setting. This research was conducted by Clark and Robertson (2005) and reported a meta-analysis of relationship between accident involvement and the Big Five personality dimensions. Another is the work of Schmukle and Egloff (2005), which analysed the extent of occasion specific effects on Implicit Association Tests (IATs) for assessing implicit self-concepts of personality traits. In order to compare the results obtained from different traits; both anxiety and extraversion were assessed. A short five-factor personality inventory developed from the International Personality Item Pool (IPIP) was implemented as online questionnaire by Buchanan, Johnson, and Golberg (2005). The result of this work shows an acceptable measure of the Five-factor model for use in internet-mediated research. A number of other personality scales have been implemented as on-line instruments. Studies on personality assessment started over 40 years ago in psychology with works like MMPI \& MMPI-2 (Hathaway \& Mckinley, 1940; Helmes \& Reddon, 1993) and 16-PF Test (Cattell, 1965).

However, nowadays, the effects of personality traits are being examined across all disciplines. This is because personality is concerned with human beings, who are key actors or resources in all spheres of lives. Some of the disciplines where personality traits would certainly have signifi- 
cant influence on performance are the application areas of Information System, Software engineering or Computer Science.

Wang and King (2006) explored the characteristics of human factors and their influences in engineering. He presented a similar work that applies Real-Time Process Algebra (RPTA) to describe the motivations and attitudes in software engineering (Wang, 2005). Wynekoop and Walz (1998) examined the differences in personality profiles of key IT personnel and found out that there are clear differences. Similar to this, is the work of Chilton and Hardgrave (2004), which assessed the behavioural skills (Technical and Managerial) and determined the relationship between these skills and personality traits.

Houghton (2004) introduced a theoretical framework for understanding the role of personal traits in collaboration in virtual contexts. The work stated that individual traits and dyadic complementarities are mediating factors in interpersonal trust and willingness to use new technologies and significantly affect the initiation, duration, and productivity of computer-mediated collaboration. Another interesting work is conducted by Dick and Zarnett (2002) on paired programming and personality traits. The work was carried out to determine whether the members have personality traits that are needed for maximum performance. The work then suggested that the team members in Paired or Extreme programming should be selected based on personality traits that are beneficiary to paired programming approach. Howard (2001) emphasized in his paper the need to check whether software engineers have got the right personality for the job.

We have seen that a lot of previous work stressing the need to assess the personality trait of IT personnel, but none has really provided a technique for doing this. Also, Software Engineers have their typical fields like designing, programming, testing, etc., it is important to determine whether they have the right personalities for the chosen field.

This is a major interest in this work.

\section{Design Methodology}

\section{Personality Traits}

A personality trait is a consistent and long-lasting tendency in behaviour. There are different personality traits that people normally exhibit. The Big five personality factors as proposed by Goldberg (1990) are used widely to classify personality traits and are used as the basis for the assessment model in section 4. The Big five personality factors consist of Neuroticism, Extraversion, Agreeableness, Conscientiousness and Openness to experience. SE is a technical and complex activity that requires a high level of cognitive ability. The success and otherwise of software development depends on cognitive factors such as mindset, abstract thinking, analytic, visualization capability, and so on. Consequently, the Big five personality factors can not be adequately used to assess personality trait in SE. In this work, we have introduced an additional factor called Cognitie Ability, to the Big five factors. The new SE-Personality assessment factors are represented in Figure 1.

a. Neuroticism:- This is the tendency to experience unpleasant emotions relatively easily. Its components are anxiety, hostility, depression, self-consciousness, and impulsiveness. The opposite is emotional stability or self-control.

People who are high in this factor have the following features:-

$>$ They are faced with effect of decreasing cognitive and performance capacities (Mathews et al., 1991)

$>$ They have increasing probability of errors 
They are more distracted from the task at hand (Hansen, 1989)

$>$ They have tendency to experience greater stress symptoms

$>$ They tend to be pre-occupied with their anxieties and worries

$>$ There is also evidence that they do not seek active control of the environment (Judge, 1993)

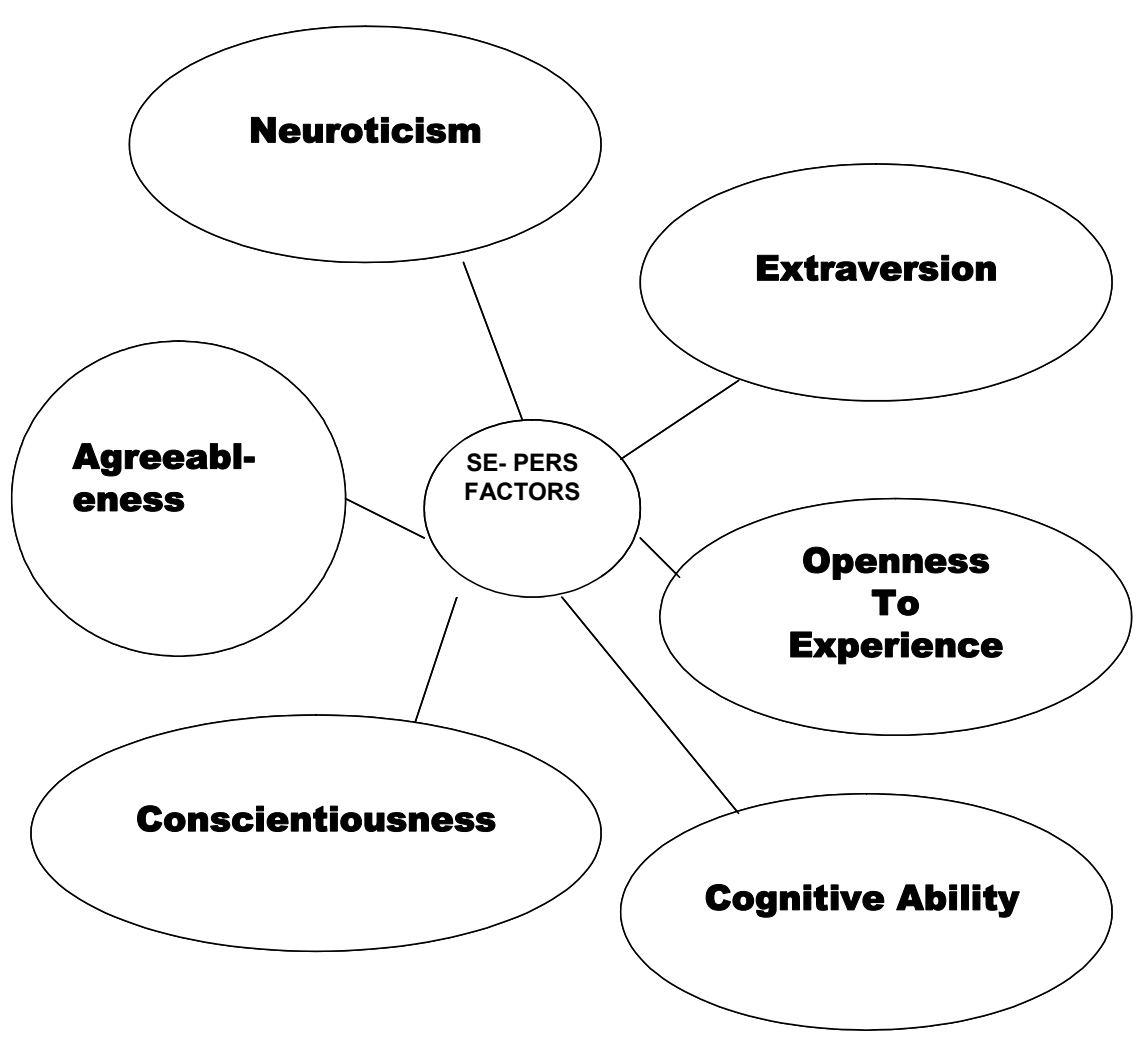

Figure 1: SE- Six personality assessment factors

b. Extraversion:- This is the tendency to seek simulation and enjoy the company of other people. Its components include warmth, sociable, assertive, energetic, adventurous, and enthusiastic.

People who are high in this factor have the following features:-

$>$ They are sensitive to monotony (Thiffault \& Bergeron, 2003)

$>$ They are high sensation seekers and have a greater tendency to take risks (Jonah, 1997)

$>$ They demonstrate significantly poorer performance on vigilance tasks (Koelega, 1992)

c. Conscientiousness:- This is the tendency to show self-discipline, to be dutiful, and to strive for achievement and competence. Its components also include self-discipline, consultative, competence, order, dutifulness and thorough.

People who are high in this factor have the following features:-

$>$ They are always thorough in decision-making style (Clarke \& Robertson, 2005) 
D They follow rules and regulations (Arthur \& Doverspike, 2001)

$>$ They are interested in goal targeting and systematic approach

$>$ They are always interested in providing adequate cost-benefit analysis and contingency planning (West et al., 1993)

$>$ They are less vulnerable to cognitive failures

d. Agreeableness:- This is the tendency to be compassionate towards others and not antagonistic. Its components include pleasant, tolerant, tactful, helpful, trust, respectful, sympathetic and modest.

People who are high in this factor have the following features:-

$>$ They are generally easy to get along with (Hough, 1992)

$>$ They are salient in situations that involve interaction or cooperation with others (Barrick \& Mount, 1991)

$>$ They are less aggressive

$>$ They are emotionally stable

$>$ They are trustworthy and compliance (Clarke \& Robertson, 2005)

e. Openness to experience:- This is the tendency to enjoy new intellectual experiences and ideas. Its components include imaginative, curious, unconventional, broadminded and cultured.

People who are high in this factor have the following features:-

They have positive disposition towards learning (Salgado, 2002)

They tend to be liable to rule violations, experimentation and improvisation (Clarke \& Robertson, 2005)

They are less suitable for safety critical tasks

f. Cognitive Ability:- This is a factor added to the big five factors because of the requirement of SE. It has the following components:-

i. $\quad$ Abstract level thinking:- This is the ability to conceive an idea or concept without any relation to any practical instance. It can be simply put as theoretical analysis.

ii. Mindset:- A fixed mental attitude or disposition that predetermines a person's responses to and interpretation of the situation. It typically has to do with the collective responses and interpretation of the situation by individuals.

iii. Analytic:- This is reasoning or capable of reasoning in clear and consistent manner. It is reasoning and or acting from a perception of the parts and interrelations of actions.

iv. Concentration capability:- This is the ability to provide constant and productive undivided attention to events.

v. Expressiveness:- Ability to present one's ideas in acceptable forms to others.

vi. Visualisation capability:- The ability to provide a technique or method for seeing the unseen. It is also the ability to use metal model to describe or represent events. 


\section{Review of Software Development Stages}

Since this work is based on SE, we present a review of activities in SE in order to appreciate the significance of personality traits. Figure 2 shows the stages in SE and Table 3 presents the summary of activities in SE.

SOFTWARE DEVELOPMENT STAGES

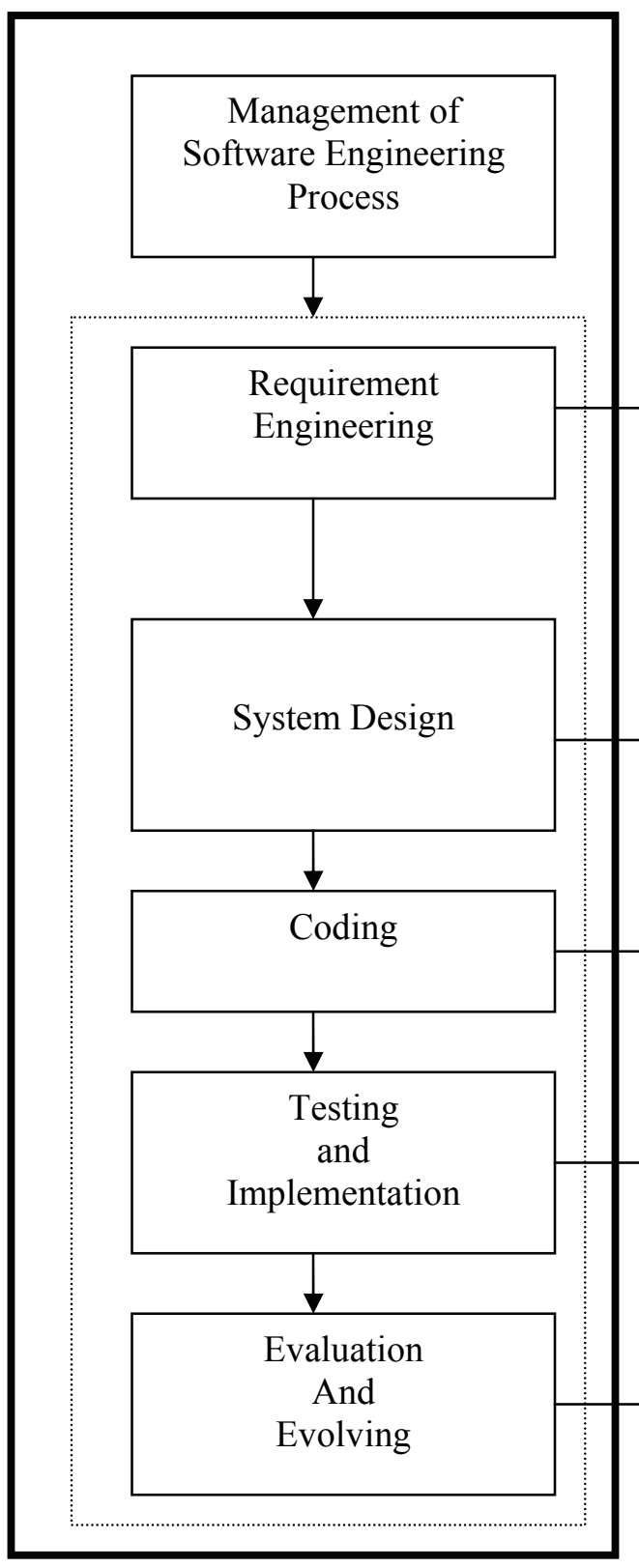

KEY SOFTWARE ENGINEERS

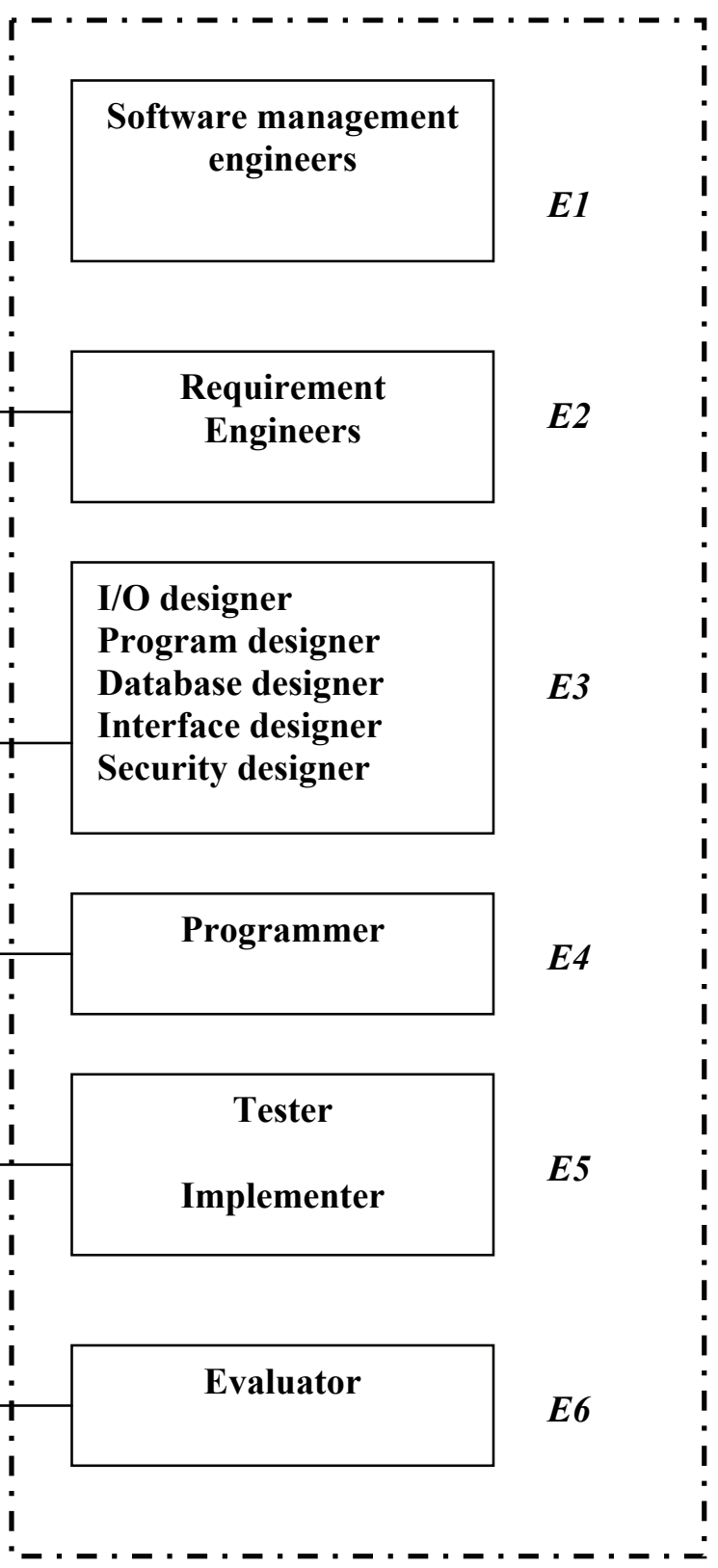

Figure 2: Representation of Software Development Stages and Software Engineers 
It can also be seen from Figure 2 that the different categories of software engineers are represented using E1, E2, E3, E4, E5, and E6.

Table 1: Summary of activities and engineers in software engineering

\begin{tabular}{|c|c|c|c|c|}
\hline $\begin{array}{l}\text { S/ } \\
\text { No }\end{array}$ & Processes & $\begin{array}{l}\text { Sub-products/ } \\
\text { Products }\end{array}$ & Roles & Summary of activities \\
\hline 1. & $\begin{array}{l}\text { Software } \\
\text { engineering } \\
\text { process } \\
\text { management }\end{array}$ & $\begin{array}{l}\text { Successful } \\
\text { software product }\end{array}$ & $\begin{array}{ll}\text { a. } & \text { Project manager } \\
\text { b. } & \text { Project-level process designer } \\
\text { c. } & \text { Project plan \& estimation engi- } \\
& \text { neer } \\
\text { d. } & \text { Quality engineers } \\
\text { e. } & \text { Project team coordinator } \\
\text { f. } & \text { Software development organi- } \\
& \text { zation manager } \\
\text { g. } & \text { Software environment and } \\
& \text { tools manager } \\
\text { h. } & \begin{array}{l}\text { Software environment and } \\
\text { tools maintenance }\end{array} \\
\end{array}$ & $\begin{array}{l}\text { - Project } \\
\text { organization } \\
\text { - Staffing } \\
\text { - Planning and } \\
\text { estimating } \\
\text { - Coordination } \\
\text { - Quality control }\end{array}$ \\
\hline 2. & $\begin{array}{l}\text { Requirement } \\
\text { analysis }\end{array}$ & $\begin{array}{l}\text { System } \\
\text { specification }\end{array}$ & $\begin{array}{l}\text { a. Requirement capture engineer } \\
\text { b. Customer solution engineer } \\
\text { c. Requirement analyst } \\
\text { d. System analyst } \\
\text { e. System requirement } \\
\text { specification analyst } \\
\text { f. Project control and } \\
\text { requirement manager }\end{array}$ & $\begin{array}{l}\text { - Fact findings } \\
\text { - Investigating the } \\
\text { current system } \\
\text { - Modeling the } \\
\text { current system } \\
\text { - Logical models of } \\
\text { the required system }\end{array}$ \\
\hline 3. & System design & $\begin{array}{l}\text { System } \\
\text { architecture }\end{array}$ & $\begin{array}{l}\text { a. Software engineering } \\
\text { process designer } \\
\text { b. Interface designer } \\
\text { c. Software engineering } \\
\text { methodology designer } \\
\text { d. Domain engineer } \\
\text { e. System architect }\end{array}$ & $\begin{array}{l}\text { - Structuring and } \\
\text { partitioning of the } \\
\text { design into } \\
\text { software sub- } \\
\text { components } \\
\text { - Detailed design of } \\
\text { the components } \\
\text { - Formation of the } \\
\text { system structure } \\
\text { and relationships }\end{array}$ \\
\hline 4. & Coding & $\begin{array}{l}\text { Working } \\
\text { software } \\
\text { modules }\end{array}$ & $\begin{array}{l}\text { a. Algorithm developer } \\
\text { b. Programmer }\end{array}$ & $\begin{array}{l}\text { - Programming } \\
\text { components of the } \\
\text { system } \\
\text { - Unit testing }\end{array}$ \\
\hline 5. & $\begin{array}{l}\text { System testing and } \\
\text { integration }\end{array}$ & $\begin{array}{l}\text { Complete } \\
\text { software product }\end{array}$ & $\begin{array}{l}\text { a. User testing coordinator } \\
\text { b. Software testing } \\
\text { engineer } \\
\text { c. System integration and } \\
\text { configuration engineer }\end{array}$ & $\begin{array}{l}\text { - Integrating } \\
\text { subcomponents } \\
\text { together } \\
\text { - Integration testing } \\
\text { - System testing to } \\
\text { ensure that the } \\
\text { system meets its } \\
\text { requirements }\end{array}$ \\
\hline 6. & $\begin{array}{l}\text { Delivery and } \\
\text { Maintenance }\end{array}$ & $\begin{array}{l}\text { Working/ } \\
\text { Implemented } \\
\text { software }\end{array}$ & $\begin{array}{l}\text { a. Delivered system manager } \\
\text { b. Maintenance engineer } \\
\text { c. Technical trainer } \\
\text { d. User technical supporter } \\
\text { e. System service evaluator }\end{array}$ & $\begin{array}{l}\text { - Installing the } \\
\text { system in 'live' } \\
\text { environment } \\
\text { - Training the users } \\
\text { - Maintenance } \\
\text { - Implementing } \\
\text { enhancements as } \\
\text { demanded by } \\
\text { changes in users' needs }\end{array}$ \\
\hline
\end{tabular}




\section{Cogno-Personality Model for Software Engineering}

\section{Research Survey}

To adequately construct the Cogno-Personality Assessment Model for Software Engineering (CPAMSE), a research survey was conducted in order to capture information about personality requirements for different roles in SE.

\section{a. Data gathering techniques}

A well-structured questionnaire was administered to 112 software project team leaders in 19 software development organisations in Nigeria. The essence of this selection is to gather information about personality traits of software engineers within these teams and their effects on team performance from team leaders. The 112 team leaders gave personality and performance information on 489 software engineers.

\section{b. $\quad$ Summary of survey result}

The summary of the survey result is presented in Table 2 . The required levels of personality traits suggested by the team leaders in order to attain high performance for different roles in SE are given in column five. The levels of trait (Low, Medium, High) were indicated by the teams leaders of these engineers. According to Table 2, row 1 means that out of 489 software engineers considered, 36 were software process engineers. Out of these 36, 33 of them had high performance rating. Out of these 33, 30(91\%) had the trait level for Neuroticism to be low. The remaining $3(9 \%)$ had the trait level for Neuroticism to either be medium or high. The same explanation goes to for others. With this result, we concluded that software process engineers must have a trait level for neuroticism to be low.

Table 2: Summary of Personality Assessment Survey Result

\begin{tabular}{|c|c|c|c|c|}
\hline \multirow[t]{2}{*}{ Roles } & \multirow{2}{*}{$\begin{array}{l}\text { Total } \\
\text { Number of } \\
\text { Engineers }\end{array}$} & \multirow{2}{*}{$\begin{array}{l}\text { Personality } \\
\text { Traits }\end{array}$} & \multicolumn{2}{|c|}{ High Performance } \\
\hline & & & $\begin{array}{l}\text { No. for High } \\
\text { Performance }\end{array}$ & Level of Trait \\
\hline \multirow{6}{*}{$\begin{array}{l}\text { Software process } \\
\text { management }\end{array}$} & \multirow[t]{6}{*}{36} & $\mathrm{~N}$ & 33 & Low $(30-91 \%)$ \\
\hline & & $\mathrm{E}$ & 32 & Low $(27-84 \%)$ \\
\hline & & $\mathrm{O}$ & 30 & Medium(26-87\%) \\
\hline & & $\mathrm{CC}$ & 29 & Medium(28-97\%) \\
\hline & & $\mathrm{C}$ & 31 & Medium(28-90\%) \\
\hline & & $\mathrm{A}$ & 31 & $\operatorname{High}(25-81 \%)$ \\
\hline \multirow{6}{*}{$\begin{array}{l}\text { Requirements } \\
\text { Analysis }\end{array}$} & \multirow[t]{6}{*}{67} & $\mathrm{~N}$ & 65 & Low $(55-85 \%)$ \\
\hline & & $\mathrm{E}$ & 63 & Medium $(60-95 \%)$ \\
\hline & & $\mathrm{O}$ & 61 & Low $(54-89 \%)$ \\
\hline & & $\mathrm{CC}$ & 63 & $\operatorname{High}(51-81 \%)$ \\
\hline & & $\mathrm{C}$ & 64 & $\operatorname{High}(50-78 \%)$ \\
\hline & & $\mathrm{A}$ & 65 & $\operatorname{High}(48-74 \%)$ \\
\hline
\end{tabular}




\begin{tabular}{|c|c|c|c|c|}
\hline \multirow[t]{6}{*}{ System Design } & \multirow[t]{6}{*}{64} & $\mathrm{~N}$ & 57 & Low $(51-89 \%)$ \\
\hline & & $\mathrm{E}$ & 61 & Low $(60-98 \%)$ \\
\hline & & $\mathrm{O}$ & 62 & $\operatorname{Low}(62-100 \%)$ \\
\hline & & $\mathrm{CC}$ & 59 & $\operatorname{High}(53-90 \%)$ \\
\hline & & $\mathrm{C}$ & 60 & $\operatorname{High}(49-82 \%)$ \\
\hline & & A & 63 & $\operatorname{High}(45-71 \%)$ \\
\hline \multirow[t]{6}{*}{ Coding } & \multirow[t]{6}{*}{183} & $\mathrm{~N}$ & 167 & Low $(121-72 \%)$ \\
\hline & & $E$ & 165 & Low $(142-86 \%)$ \\
\hline & & $\mathrm{O}$ & 175 & $\operatorname{Low}(171-98 \%)$ \\
\hline & & $\mathrm{CC}$ & 177 & $\operatorname{High}(173-98 \%)$ \\
\hline & & $\mathrm{C}$ & 169 & Medium(129-76\%) \\
\hline & & A & 180 & $\operatorname{High}(168-93 \%)$ \\
\hline \multirow{6}{*}{$\begin{array}{l}\text { System Testing } \\
\text { and Integration }\end{array}$} & \multirow[t]{6}{*}{87} & $\mathrm{~N}$ & 86 & Low $(76-88 \%)$ \\
\hline & & $\mathrm{E}$ & 84 & Medium(71 - 85\%) \\
\hline & & $\mathrm{O}$ & 80 & $\operatorname{High}(62-78 \%)$ \\
\hline & & $\mathrm{CC}$ & 79 & $\operatorname{High}(64-81 \%)$ \\
\hline & & $\mathrm{C}$ & 85 & Medium(81-95\%) \\
\hline & & A & 86 & $\operatorname{High}(77-90 \%)$ \\
\hline \multirow{6}{*}{$\begin{array}{l}\text { Delivery and } \\
\text { Maintenance }\end{array}$} & \multirow[t]{6}{*}{52} & $\mathrm{~N}$ & 46 & Low(41-89\%) \\
\hline & & $\mathrm{E}$ & 47 & Low(42-89\%) \\
\hline & & $\mathrm{O}$ & 42 & Medium(40-95\%) \\
\hline & & $\mathrm{CC}$ & 42 & Medium(34-81\%) \\
\hline & & $\mathrm{C}$ & 41 & $\operatorname{High}(35-85 \%)$ \\
\hline & & A & 48 & $\operatorname{High}(42-88 \%)$ \\
\hline
\end{tabular}

\section{The Model - CPAMSE}

The result of this survey is then used to construct the Cogno-Personality Assessment Model for Software Engineering (CPAMSE) as shown in Figure 3. 


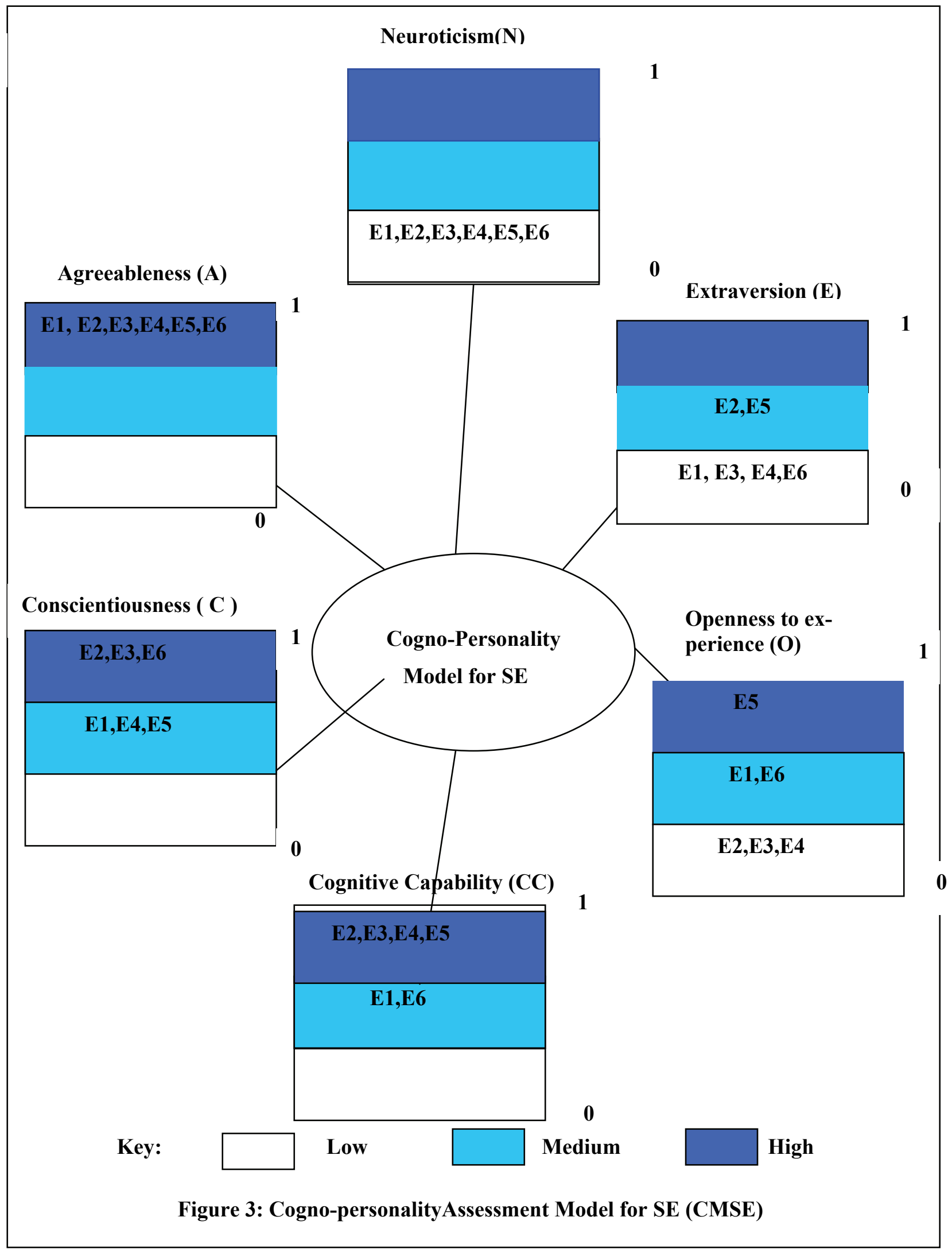


The boxes in the model represent the six trait factors. The probability that an individual possess a personality factor is denoted by $\lambda$.

Generaly, $\lambda\left(F_{i}\right)$ denotes the probability that a person has trait factor $F_{i}, i=1, \ldots, 6$

For example, $\lambda(\mathrm{N})$ denotes that the probability that a software engineer possess personality factor $\mathrm{N}$ (Neuroticism). The range of $\lambda$ is from 0 (at the bottom corner of the box) to 1 (at the upper corner) for all factors. $S$ represents the personality space.

Then

$S=\mathrm{N}+\mathrm{E}+\mathrm{A}+\mathrm{O}+\mathrm{C}+\mathrm{CC}$

and $S-(\mathrm{N}+\mathrm{E}+\mathrm{A}+\mathrm{O}+\mathrm{C}+\mathrm{CC})=\varnothing$.

Trait Status (TS) represents the levels of $\lambda$. The different classifications of TS are

i. $\quad$ If $\lambda=0$ then TS is not existing, i.e. TS $(\varnothing)$

ii. If $\lambda>0$ and $\lambda<0.4$, then TS is Low, i.e. TS(Low)

iii. If $\lambda>=0.4$. and $\lambda<0.7$, then TS is Medium, i.e. TS(Medium)

iv. If $\lambda>=0.7$, then TS is High, i.e. TS(High)

CPAMSE shows the required trait status (TS) in SE. Different layers within the boxes represent the TS.

For example, it can be seen from the model that the requirements for Extraversion are as follows:

$\mathrm{E} 1, \mathrm{E} 2 \rightarrow \mathrm{TS}($ Low $)$

$\mathrm{E} 2, \mathrm{E} 4, \mathrm{E} 5 \rightarrow \mathrm{TS}(\mathrm{Low})$

$\rightarrow$ Denotes "require"

The key at the bottom of the model represents different TS categories.

\section{The Assessment Technique}

The assessment technique is based on on-line questionnaire to be filled by intending software engineers. One question each was collected for each personality factor from five experts in psychology. This results in a total of 30 questions (6 X 5) that are used to assess Personality Trait Level (PTL) on intending software engineers. Trait Status Score (TSS) compares what is TS required with the TS computed and if there is a match, a score of 1 is assigned to TSS.

For example:

Coding engineers requires TS(N) to be low $(0-0.4)$. TS $(\mathrm{N})$ would be obtained based on the responses to 5 questions to assess neuroticism.

If $\mathrm{TS}(\mathrm{N})$ falls between the range of $0-0.4$, a score of 1 is assigned to Trait Status Score (TSS). The same thing goes for all other factors.

$$
\mathrm{PTL}=(\mathrm{TSS}(\mathrm{N})+\mathrm{TSS}(\mathrm{E})+\mathrm{TSS}(\mathrm{O})+\mathrm{TSS}(\mathrm{CC})+\mathrm{TSS}(\mathrm{C})+\mathrm{TSS}(\mathrm{A})) / 6
$$

The PTL for all the roles in SE are computed and the fitness for roles in SE is determined by the highest values of PTL.

\section{Implementation and Evaluation Procedure}

As it was mentioned earlier, the on-line questionnaire was constructed based questions from 5 different experts in psychology. The idea is to get mixed expert ideas in order to make the tool robust. The assessment tool allows users to respond to 36 questions by selecting options and recommends the three best roles in SE suitable for the user based on personality traits. The assess- 
ment tool was implemented using Visual Basic. The interface screens for responding to questions and for presentation of roles recommendation are presented in Figures 4 and 5.

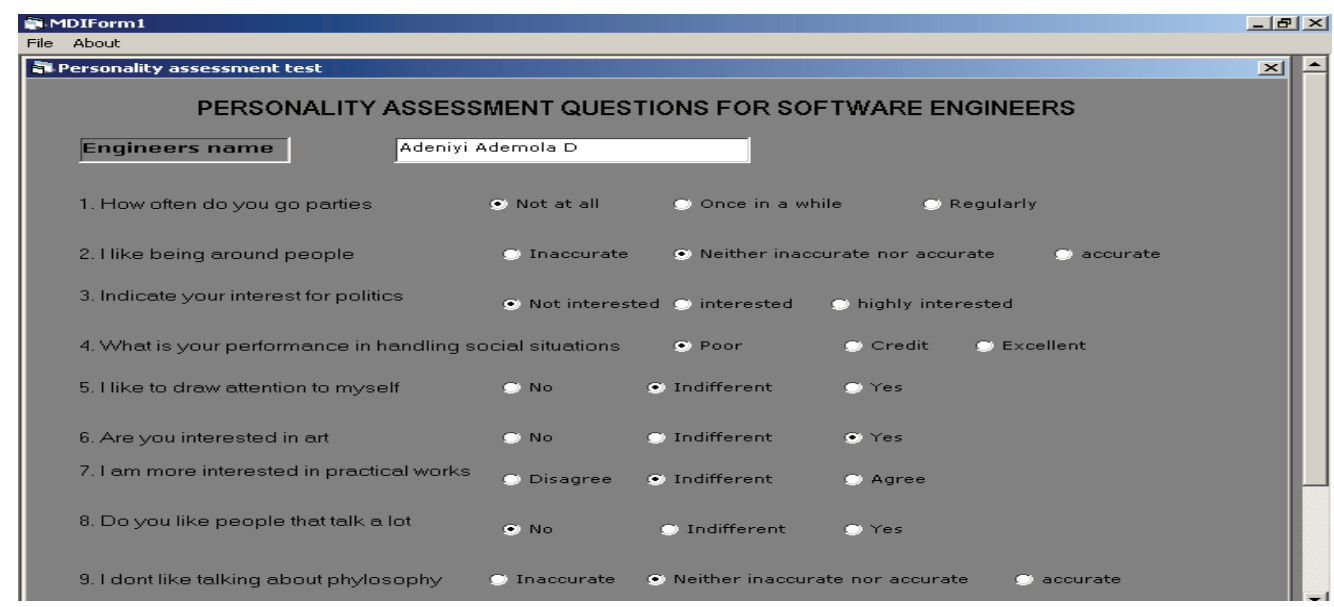

Figure 4: Interface for responding to the on-line questionnaire

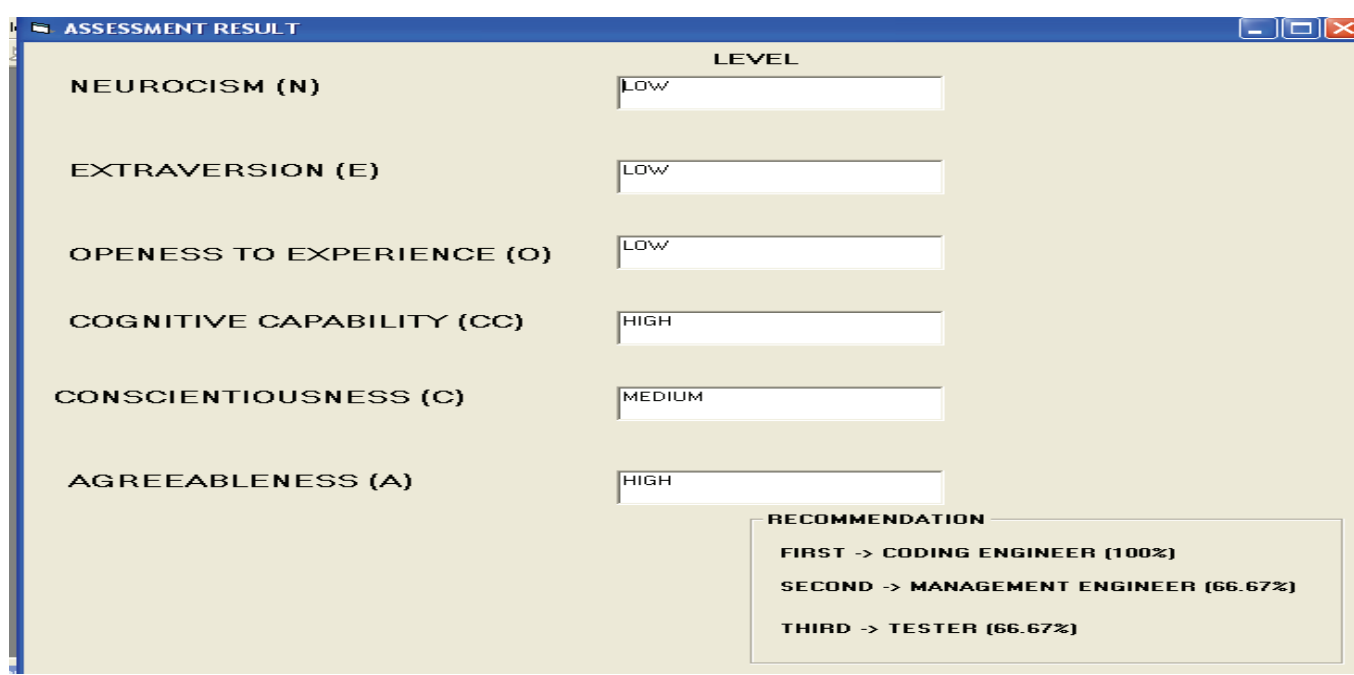

Figure 5: Personality Assessment Result

\section{First Evaluation}

The 58-numbered final year students of the department of computer science, University of Agriculture, Abeokuta, Nigeria were used as test case. They were made to respond to the online questionnaire and the tool recommended the best roles in software engineering that their personality traits conform with. The summary of the evaluation result is presented in Table 3.

This shows that 6 students are best to be management engineers, 11 best suited to be requirement engineers and so on. The tool also recommended the second and third fitted roles in SE for these students. 
Table 3: Summary of first Personality Assessment results

\begin{tabular}{|l|l|l|l|l|l|l|}
\cline { 2 - 8 } \multicolumn{1}{c|}{} & \multicolumn{3}{c|}{$\begin{array}{c}\text { First Assessment } \\
\text { Recommendation }\end{array}$} & \multicolumn{3}{c|}{$\begin{array}{c}\text { Second Assessment } \\
\text { Recommendation }\end{array}$} \\
\hline & First & Second & Third & First & Second & Third \\
\hline Management Engineer & 8 & 7 & 13 & 9 & 8 & 11 \\
\hline Requirement Engineer & 13 & 12 & 8 & 12 & 13 & 7 \\
\hline System Engineer & 12 & 11 & 10 & 11 & 10 & 9 \\
\hline Programmer & 9 & 8 & 11 & 10 & 7 & 12 \\
\hline Tester and Implementer & 10 & 13 & 9 & 9 & 12 & 10 \\
\hline Evaluator & 6 & 7 & 7 & 7 & 8 & 9 \\
\hline
\end{tabular}

\section{Second Evaluation}

We first capture data about personality traits of 1002 software engineers using questionnaire. Personality information about the engineers was given the heads. We then compared the two results together. Table 4 shows that only 21 out of 1002 considered did not give the same personality status with our own assessment technique in neuroticism. The same goes for other traits. This shows that our system is efficient.

Table 4: Summary of second Personality Assessment results

\begin{tabular}{|l|l|l|}
\hline Traits & Variation & Percentage \\
\hline $\mathrm{N}$ & 21 & $0.0209 \%$ \\
\hline $\mathrm{E}$ & 5 & $0.0049 \%$ \\
\hline $\mathrm{O}$ & 33 & $0.0329 \%$ \\
\hline $\mathrm{CC}$ & 4 & $0.0039 \%$ \\
\hline $\mathrm{C}$ & 51 & $0.0509 \%$ \\
\hline $\mathrm{A}$ & 46 & $0.0459 \%$ \\
\hline
\end{tabular}

\section{Future Work and Conclusion}

The work can also be extended to personality based team formation in SE. Researchers in this area should also be interested in formal and mathematical assessment of personality assessment.

We have successfully designed and implemented tool for personality in SE. This work is considered very important because of the roles of personality trait in productivity and job performance. This work has presented a way of putting right people in the right place in other to achieve effective job interest.

\section{References}

Arthur, W. \& Doverspike, D. (2001). Predicting motor vehicle crash involvement from a personality measure and a driving knowledge test. Journal of Prevention and Intervention in the Community, 22, 35-42.

Barrick, M. R. \& Mount, M. K. (1991). The big five personality dimensions and job performance: A metaanalysis. Journal of Personnel Psychology, 44, 1-26.

Buchanan, T., Johnson, J. A., \& Golberg, L. R. (2005). Implementing a five-factor personality inventory for use on the Internet. European Journal of Psychological Assessment, 21(2), 115-127

Cattell, R. B. (1965). The scientific analysis of personality. Chicago: Aldine.

Chilton, M. A., \& Hardgrave, B. C. (2004). Assessing information technology personnel: Toward a behavioral rating scale. The DATABASE for Advances in Information Systems, 35(3). 
Clarke, S. \& Robertson, I. T. (2005). A meta-analytic review of the big five personality factors and accident involvement in occupational and non-occupational settings. Journal of Occupational and Organisational Psychology, 78, 355-376.

Dick, A. J., \& Zarnett, B. (2001). Paired programming \& personality traits. Third International Conference on XP and Agile Processes in Software Engineering, May 26-29, 2002, Alghero, Sardinia, Italy

Goldberg, L. R. (1990). An alternative "description of personality": The big-five factor structure. Journal of Personality and Social Psychology, 59, 1216-1229.

Hansen, C. P. (1989). A casual model of the relationship among accidents, biodata, personality and cognitive factors. Journal of Applied Psychology, 74, 81-90.

Hathaway, S. R. \& Mckinley, J. C. (1940). A multiphasic personality schedule (Minnesota): I. Construction of the schedule. Journal of Psychology, 10, 249-254.

Helmes, E. \& Reddor, J. R. (1993). A perspective on developments in assessing psychopathology: A critical review of the MMPI and MMPI-2. Psychological Bulletin, 113, 543-471.

Hough, I. M. (1992). The 'big five'personality variables - Construct confusion. Journal of Human Performance, 5, 139-155.

Houghton, G. B. (2004). Interpersonal traits, complementarity, and trust in virtual collaboration. Journal of Management Information System, 20(4).

Howard, A. (2001). Software engineering project management. Communications of the ACM, 44(5).

Hughes, B. \& Cotterell, M. (2002). Software project management (3rd ed.). MacGraw-Hill.

Jonah, B. A. (1997). Sensation seeking and risky driving. In T. Rothengatter \& E. Carbonell Vaya (Eds.), Traffic and transport psychology: Theory and application (pp. 259-267). Oxford: Pergamon.

Judge, T. A. (1993). Does affective disposition moderate the relationship between job satisfaction and voluntary turnover? Journal of Applied Psychology, 78, 395-401.

Kalat, J. W. (1999). Introduction to psychology ( $5^{\text {th }}$ ed.). International Thomson Publishing Company.

Koelega, H. S. (1992). Extraversion and vigilance: 30 years of inconsistencies. Psychological Bulletin, 112, 239-258.

Mathews, G., Dorn, L., \& Glendon A. I. (1991). Personality correlates of driver stress. Journal of Personality and Individual Differences, 12, 535-549.

Salgado, J. F. (2002). The big five personality dimensions and counterproductive behaviours. International Journal of Selection and Assessment, 10, 117-125.

Schmukle, S. C., \& Egloff, B. (2005). A latent state-trait analysis of implicit and explicit personality measures. European Journal of Psychological Assessment, 21(2), 100-107.

Thiffault, P. \& Bergeron, J. (2003). Fatigue and individual differences in monotonous stimulated driving. Journal of Personality and Individual Differences, 34, 159-176.

Wang, Y (2005). On cognitive process of human perception. Cognitive Informatics. Proceedings of the 4th IEEE International Conference, (ICCI'05), IEEE CS Press, Irvine, California, USA, August.

Wang, Y. \& King, G. (2006). Software engineering processes: Principles and applications. USA: CRC Press Series.

West, R. J., Elander, J., \& French, D. (1993). Mild social deviance, type-A behaviour pattern and decision -making style as predicators of self-reported driving style and traffic accident risk. British Journal of Psychology, 84, 207-219.

Wynekoop, J. L., \& Walz, D. B. (1998). Revisiting the perennial question: Are IS people different? The DATABASE for Advances in Information Systems, 29(2). 
Young, S. M., Edwards, H. M., McDonald, S. \& Thompson, J. B. (2005). Personality characteristics in an XP team: A repertory grid study. Presented in the Workshop on Human and Social Factors of Software Engineering (HSSE), May 16, 2005, St. Louis, Missouri, USA, ACM Press.

\section{Biographies}

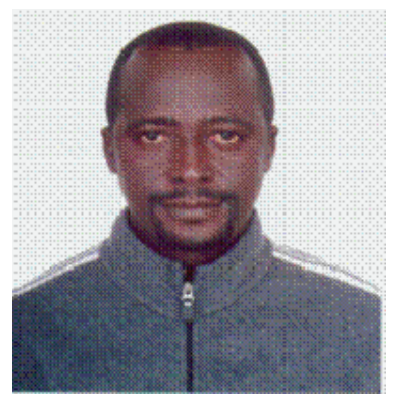

Dr. Adesina Simon Sodiya is presently a lecturer in the department of Computer Science, University of Agriculture, Abeokuta. He has published in both local and international journals. His research areas are Computer Security, Artificial Intelligence, Software Engineering, Data mining.

H. O. D. Longe [Biography not available]
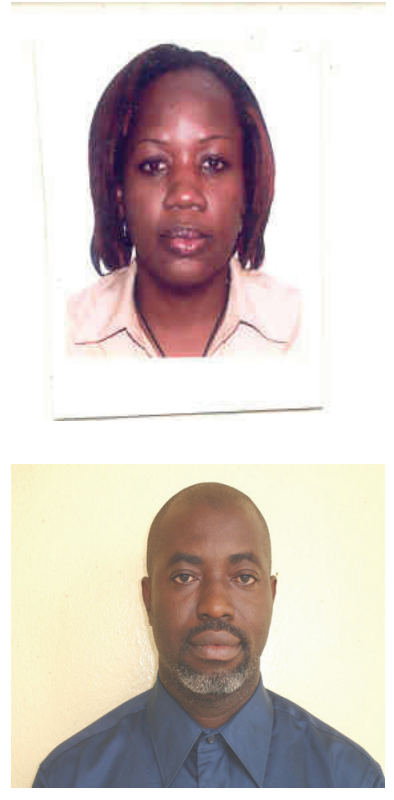

Onashoga,Saidat Adebukola (nee OKUNLAYA, formerly IBRAHIM, S. A.) has worked as a lecturer in the Department of Computer Science, University of Agriculture, Abeokuta, Nigeria for the past six years. She had her degrees in University of Agriculture, Abeokuta, Nigeria with M.Sc. in Computer Science (2004), B.Sc. Mathematical Science (Computer Science option, 2000). She is currently on her Ph.D. programme in Computer Science in the same University. She has published in both International and local journals. Her current research interests include Network Security, Data Mining and Knowledge Management. She is married.

Awodele Oludele is presently a lecturer in the department of computer science \& maths, Babcock University, Ilisan-Remo, Ogun state, Nigeria. He had his M.Sc in Computer Science, 2002 at the University of Agricuture Abeokuta, PGD in computer Science and BSc Mathemathis both at the University of Ilorin 1998 and 1995 respectively. He is currently on his Ph.D programme in computer Science in the University of Agriculture Abeokuta. His research ares are Software Engineering, Data Communication and artificial Intelligence.

L. O. Omotosho [Biography not available] 